ISTIGHNA, Vol. 3, No 2, Juli 2020 P-ISSN 1979-2824 E-ISSN 2655-8459

Homepage: http://e-journal.stit-islamic-village.ac.id/index.php/istighna

Naila Attamimi

Hubungan Gaya Kepemimpinan Transformasional dan Supervisi Kepala Sekolah Serta Iklim Kerja Terhadap Kinerja Guru di SMP Kecamatan Cikande Kabupaten Serang

\title{
HUBUNGAN GAYA KEPEMIMPINAN TRANSFORMASIONAL DAN SUPERVISI KEPALA SEKOLAH SERTA IKLIM KERJA TERHADAP KINERJA GURU DI SMP KECAMATAN CIKANDE KABUPATEN SERANG
}

\author{
Naila Attamimi \\ Naila.atamimi@gmail.com \\ Sekolah Tinggi Teknik Multimedia Cendekia Abditama Tangerang - Indonesia
}

\begin{abstract}
The purpose of this study is to find out: 1). The relationship between the principal's transformational leadership style and teacher performance in SMP Cikande, Serang Regency 2). The relationship between the supervision of the school principal and the performance of teachers in SMP Cikande, Serang, 3). The relationship between work climate and teacher performance in SMP Cikande, Serang Regency, 4). The relationship between transformational leadership style, supervision of school principals, and work climate on teacher performance in SMP Cikande Serang District. This study uses quantitative research methods through surveys with questionnaires. The target population in this study were all teachers, amounting to 75 people in the Cikande Serang (4 junior high schools out of 8 Junior High Schools in the Cikande Serang District). Samples were taken intentionally. This data collection is done by using a questionnaire. The results of data collection were further analyzed using simple correlation data analysis techniques, multiple correlations, significance tests, and coefficient of determination with the help of SPSS 16. The results showed that: (1) Correlation of the transformational leadership style of school principals (X1) on teacher performance (Y) in the good category, which is 0.632 . (2) the correlation between supervision of school principals (X2) and teacher performance (Y) is in the good category, that is 0.657 (3) work climate (X3) to teacher performance (Y) is in the medium category, that is 0.479 ; (4) the contribution of the principal's transformational leadership style (X1) to the supervision of the principal (X2) and work climate (X3) to the teacher's performance (Y) 0.73 .
\end{abstract}

Keywords: Transformational Leadership, Teacher Performance, Work Climate

\footnotetext{
Abstrak: Tujuan penelitian ini adalah untuk mengetahui:1). Hubungan gaya kepemimpinan transformasional kepala sekolah dengan kinerja guru di SMP Kecamatan Cikande Kabupaten Serang 2). Hubungan supervisi kepala sekolah dengan kinerja guru di SMP Kecamatan Cikande Kabupaten Serang, 3). Hubungan antara iklim kerja dengan kinerja guru di SMP Kecamatan Cikande Kabupaten Serang, 4). Hubungan antara gaya kepemimpinan transformasional, supervisi kepala sekolah, dan iklim kerja terhadap kinerja guru di SMP Kecamatan Cikande Kabupaten Serang.Penelitian ini menggunakan metode penelitian kuantitatif melalui survei dengan penyebaran kuesioner. Target populasi dalam penelitian ini adalah seluruh guru yang berjumlah 75 orang di SMP Kecamatan Cikande kabupaten Serang (dipilih 4 SMP dari 8 SMP yang berada di Kecamatan Cikande

Peer reviewed under reponsibility of STIT ISLAMIC VILLAGE.

(C) 2018 STIT ISLAMIC VILLAGE, All right reserved, This is an open access article under 181 the CC BY SA license (https://creativecommons.org/licenses/by-sa/4.0/)
} 
ISTIGHNA, Vol. 3, No 2, Juli 2020 P-ISSN 1979-2824

Homepage: http://e-journal.stit-islamic-village.ac.id/index.php/istighna

Naila Attamimi

Hubungan Gaya Kepemimpinan Transformasional dan Supervisi Kepala Sekolah Serta Iklim Kerja Terhadap Kinerja Guru di SMP Kecamatan Cikande Kabupaten Serang

Kabupaten Serang). Sampel di ambil secara sengaja. Pengumpulan data ini dilakukan dengan menggunakan alat kuesioner. Hasil pengumpulan data selanjutnya dianalisis menggunakkan teknik analisis data korelasi sederhana, korelasi ganda, uji sifnifikansi, dan koefisien determinasi dengan bantuan SPSS 16. Hasil penelitian menunjukkan bahwa: (1) Korelasi variabel gaya kepemimpinan transformasional kepala sekolah (X1) terhadap kinerja guru (Y) ada pada kategori baik, yaitu 0,632. (2) korelasi supervisi kepala sekolah (X2) terhadap kinerja guru (Y) ada pada kategori baik, yaitu 0,657 (3) iklim kerja (X3) terhadap kinerja guru(Y) ada pada kategori sedang, yaitu 0,479; (4) kontribusi variabel gaya kepemimpinan transformasional kepala sekolah (X1) supervisi kepala sekolah (X2) dan iklim kerja (X3) terhadap kinerja guru(Y) 0,73.

Kata Kunci: Kepemimpinan Transformasional, Kinerja Guru, Iklim Kerja

\section{A. PENDAHULUAN}

\section{Latar Belakang}

Proses menyatunya warga dunia menjadi suatu kelompok masyrakat global dinamakan globalisasi, dengan adanya globalisasi makan akan berpengaruh terhadap suatu bangsa, masyrakat bahkan setiap individu masyrakat. Hal tersebut menimbulkan globalisasi terjadi dalam berbagai bidang, diantaranya; bidang agama, ekonomi, politik, pendidikan, sosial budaya, pertahanan serta keamanan. Globalisasi dianggap sebagai dalang dalam menyebarkan hubungan-hubungan berbagai bidang yang bisa menembus sekat-sekat geografis ruang dan waktu, dengan demikian globalisasi hampir melingkupi seluruh hal yang berkaitan dengan politik, ekonomi, inormasi, komunikasi, teknologi, transportasi dan masih banyak lainnya.

Dalam pendidikan, globalisasi membawa penggaruh yang cukup signifikan baik dalam sistem maupun kurikulum. Globalisasi di indoensia berada pada level kebingungan atau ambivalensi, karena indonesia ingin mengejar ketertinggalan kualitas pendidikan dengan negara lain tetapi pada kenyataanya indonesia belum siap atau mampu untuk mencapai kualitas tersebut. Padahal jika tidak ikut arus globalisasi pendidikan d indonesia akan semakin tertinggal. Suatu negara dikatakan maju apabila pendidkan dinegara tersebut sudah maju dan berkembang karena pendidikan memegang peranan penting dalam menjamin pertumbuhan, perkembangan serta kelangsungan hidupsuatu negara. Maka dari itu jika suatu negara ingin dikatakan maju maka penting untuk terus menerus meningkatkan mutu pendidikan.

Di abad informasi perlu adanya manajemen pendidikan yang modern dan profesional. Lembaga-lembaga pendidikan diharapkan mampu mewujdkan perananya secara efektif di dalam berbagai bidang, diantaranya; kepemimpinan, 
ISTIGHNA, Vol. 3, No 2, Juli 2020 P-ISSN 1979-2824

Homepage: http://e-journal.stit-islamic-village.ac.id/index.php/istighna

Naila Attamimi

Hubungan Gaya Kepemimpinan Transformasional dan Supervisi Kepala Sekolah Serta Iklim Kerja Terhadap Kinerja Guru di SMP Kecamatan Cikande Kabupaten Serang

guru, staf, proses belajar mmengajar, kurikulum, iklim sekolah, orangtua serta masyarakat. sosok penampilan guru yang baik adalah salah satu faktor yang berpengaruh dalam kinerja guru. Dalam mempersiapkan generasi muda yang menguasai berbagai keterampilan yang mupuni serta memiliki kecerdasan emosional dan pemberdayaan yang tinggi memerlukan peranan pendidikan.Oleh sebab itu, lembaga pendidikan dalam berbagai jenjang dan jenis membutuhkan pemberdayaan dan pencerahan dalam berbagai aspek.

\section{Kajian Teoritis}

Pendidikan adalah salah satu institusi yang berperan menyiapkan sumber daya manusia. Pendidikan merupakan suatu proses dan sistem terbuka yang berperan dalam pembentukan pribadi manusia. Pendidikan di Indonesia pada abad ke-21 mempunyai karakteristik sebagai berikut. (1) Pendidikan nasional mempunyai tiga fungsi dasar, yaitu (a) untuk mencerdaskan kehidupan bangsa; (b) untuk mempersiapkan tenaga kerja terampil dan ahli yang diperlukan dalam proses industrialisasi; (c) membina dan mengembangkan penguasaan berbagai cabang keahlian ilmu pengetahuan dan teknologi. (2) Sebagai negara kepulauan yang berbeda-beda suku, agama dan bahasa, pendidikan tidak hanya sebagai transfer pengetahuan saja, akan tetapi mempunyai fungsi pelestarian kehidupan bangsa dalam suasana persatuan dan kesatuan nasional. (3) Dengan makin meningkatnya hasil pe mbangunan, mobilitas penduduk akan mempengaruhi corak pendidikan nasional. (4) Perubahan karakteristik keluarga baik fungsi maupun struktur, akan banyak menuntut akan pentingnya kerja sama berbagai lingkungan pendidikan dan dalam keluarga sebagai intinya. (5) Asas belajar sepanjang hayat harus menjadi landasan utama dalam mewujudkan pendidikan untuk mengimbangi tantangan perkembangan zaman. (6) Penggunaan berbagai inovasi Iptek terutama media elektronik, informatika, dan komunikasi dalam berbagai kegiatan pendidikan. (7) Penyediaan perpustakaan dan sumber-sumber belajar sangat diperlukan dalam menunjang upaya pendidikan. (8) publikasi dan penelitian dalam bidang pendidikan dan bidang lain yang terkait, merupakan suatu kebutuhan nyata bagi pendidikan di abad pengetahuan. ${ }^{1}$

Tugas seorang guru bukan hanya sebagai pengajar yang melakukan transfer ilmu pengetahuan, tetapi juga sebagai pendidik yang melakukan transfer nilai-nilai sekaligus sebagai pembimbing yang memberikan pengarahan dan menuntun peserta didik dalam proses belajar. Hal ini diamanatkan dalam UU No 14 tahun 2005, tentang guru dan dosen "Guru adalah pendidik profesional dengan tugas utama mendidik, mengajar, membimbing, mengarahkan, melatih, menilai dan mengevaluasi peserta didik. Pada pendidikan anak usia dini jalur pendidikan

${ }^{1}$ Kusnandar. 2011.Guru Profesional Implementasi Kurikulum Tingkat Satuan Pendidikan (KTSP) dan Sukses dalam Sertifikasi Guru. Jakarta: Raja Garafindo. H-11 
ISTIGHNA, Vol. 3, No 2, Juli 2020 P-ISSN 1979-2824

Homepage: http://e-journal.stit-islamic-village.ac.id/index.php/istighna

Naila Attamimi

Hubungan Gaya Kepemimpinan Transformasional dan Supervisi Kepala Sekolah Serta Iklim Kerja Terhadap Kinerja Guru di SMP Kecamatan Cikande Kabupaten Serang

formal, pendidikan dasar dan pendidikan menengah". Guru merupakan elemen kunci dalam sistem pendidikan, khususnya di sekolah. Semua komponen lain, mulai dari kurikulum yang mutakhir, sarana-prasarana yang canggih, pembiayaan yang memadai, dan sebagainya tidak akan banyak memberikan efektifitas apapun terhadap kualitas pendidikan apabila esensi pembelajaran yang sesunggguhnya yaitu interaksi antara guru dengan peserta didik tidak berkualitas dan efektif. Semua komponen yang berkaitan dengan proses belajar mengajar, terutama kurikulum akan "hidup" apabila dilaksanakan oleh guru. Sebab itu lah guru tidak bisa digantikan dengan alat secanggih apapun.

Begitu pentingnya peran guru dalam mentransformasikan input-input pendidikan, sehingga kualitas seorang guru haruslah ditingkatkan, jika kualitas guru menurun maka kualitas dan efektiitas sekolahpun akan menurun.Sayangnya, dalam kultur masyarakat Indonesia sampai saat ini pekerjaan guru masih cukup tertutup. Bahkan atasan guru seperti kepala sekolah dan pengawas sekalipun tidak mudah untuk mendapatkan data dan mengamati realitas keseharian performance guru di hadapan peserta didik. Adapun program kunjungan kelas oleh kepala sekolah atau pengawas tidak mungkin ditolak oleh guru dalam kurung waktu satu tahun seklai atau enam buan sekali. Akan tetapi, tidak jarang terjadi guru berusaha menampilkan kinerja terbaiknya dalamaspek perencanaan maupun pelaksanaan pembelajaran hanya pada saat dikunjungi. Setelah itu akan kembali bekerja seperti sedia kala, kadang tanpa persiapan yang matang serta tanpa semangat dan antusiasme yang tinggi. Guru diposisikan sebagai pemegang kunci, garda terdepan serta posisi sentral di dalam pelaksanaan proses pendidikan maka guru akan menjadi bahan permasalahan terutama yang berkaitan dengan kinerja guru.

Kinerja guru merupakan kemampuan seorang guru dalam melaksanakan tugas pembelajaran di sekolah dan bertanggung jawab untuk meningkatkan prestasi peserta didik. Kinerja guru dapat ditingkatkan melalui supervisi kepala sekolah dengan tujuan meningkatkan mutu proses dan hasil pembelajaran. Kinerja guru di sekolah tentunya dipengaruhi oleh banyak faktor yang secara umum dapat digolongkan menjadi dua, yaitu pertama, faktor yang muncul dari luar diri guru dan kedua, aktor yang muncul dalam diri guru. faktor yang muncul dari luar diri guru misalnya adalah kepemimpinan kepala sekolah, budaya organisasi, struktur organisasi dan lainnya. Sedangkan faktor yang berasal dari dalam diri guru misalnya adalah kepuasan kerja, kemampuan motivasi, persepsi, pengalaman, dan lain sebagainya. Terdapat berbagai faktor yang mempengaruhi kinerja guru diantaranya tingkat pendidikan guru, jaminan kesejahteraan, supervisi kepala sekolah, program penataran, iklim yang kondusif, kondisi fisik dan mental guru, gaya kepemimpinan kepala sekolah, dan kemampuan manajerial kepala sekolah. Dalam tataran teknis kualitas kinerja guru akan sangat menentukan kualitas hasil 
ISTIGHNA, Vol. 3, No 2, Juli 2020 P-ISSN 1979-2824

Homepage: http://e-journal.stit-islamic-village.ac.id/index.php/istighna

Naila Attamimi

Hubungan Gaya Kepemimpinan Transformasional dan Supervisi Kepala Sekolah Serta Iklim Kerja Terhadap Kinerja Guru di SMP Kecamatan Cikande Kabupaten Serang

pendidikan, karena guru merupakan pihak yang paling banyak bersentuhan langsung dengan siswa dalam proses pendidikan atau pembelajaran di lembaga sekolah. $^{2}$

Kinerja mengandung makna hasil kerja, kemampuan, prestasi atau dorongan untuk melaksanakan suatu pekerjaan. Keberhasilan individu atau organisasi dalam mencapai target atau sasaran tersebut merupakan kinerja. Kinerja adalah hasil kerja seseorang dalam suatu priode tertentu yang dibandingkan dengan beberapa kemungkinan, misalnya standar target, sasaran, atau kriteria yang telah ditentukan terlebih dahulu. ${ }^{3}$

Kinerja guru adalah hasil penilaian terhadap proses dan hasil kerja yang dicapai guru dalam melaksanakan tugasnya. Kinerja tenaga pengajar adalah menyangkut seluruh aktivitas yang dilakukan oleh tenaga pengajar dalam tanggung jawabnya untuk emndidik, mengajar, membimbing, mengarahkan dan memandu peserta didik dalam rangka menggiring perkembangan peserta didik ke arah kedewasaan mental spiritual maupun fisik biologis. ${ }^{4}$ Empat hal utama terkait dengan guru kaya, bila:

(1) seorang guru memiliki cara pandang bahwa jabatan guru itu adalah profesi, oleh karena itu ia senantiasa harus dilatih keahliannya sehingga menghasilkan sosok guru yang ahli menjadi pusat intelektual dan mampu mengeendalikan sistem) dan guru perancang, guru y6ang memahami makna profesinya, memiliki visi dan merancang pengajarannya secara hidup, (2) seorang guru memiliki pola khusus dengan peserta didik yang mengedepankan sikap proaktif dan mentalitas yang kaya, (3) gurumelakukan proses pengajaran yang senantiasa tidak menantikan potensi peserta didik dan terkait antara dunia pengajaran dan dunia realitas, dan(4) seorang guru senantiasa belajar dengan mengintegrasikan otak kiri, otak kanan, pancaindar dan hatinya untuk memperoleh sumber ilmu yang hakiki."5

Dari pengertian di atas, yang dimaksud dengan kinerja guru adalah suatu pencapaian prestasi kerja guru yang dilakukan oleh guru dalam melakukan peran dan tugas dalam proses pembelajaran yang meliputi merencanakan program kegiatan pembelajaran, melaksanakan kegiatan pembelajaran, dan melakukan penilaian/evaluasi hasil pembelajaran untuk mencapai tujuan pembelajaran. Kinerja guru ini sebagai tolok ukur sejauh mana pencapaian prestasi guru dalam melaksanakan tugasnya sebagai seorang pengajar.

\footnotetext{
${ }^{2}$ Saputra, Suhar. 2010. Administrasi Pendidikan. Bandung: Refika Aditama. H-144

${ }^{3}$ Supardi. 2013. Kinerja Guru. Jakarta: PT Raja Grafindo Persada.H-147

${ }^{4}$ Hosnan. 2013. Kamus Profesional Guru. Jakarta: Yudhistira. H.174

${ }^{5}$ Aqib, Zainal.2010. Menjadi Guru Profsional Berstandar Nasional. Bandung: Yrama Widya. H-4
} 
Hubungan Gaya Kepemimpinan Transformasional dan Supervisi Kepala Sekolah Serta Iklim Kerja Terhadap Kinerja Guru di SMP Kecamatan Cikande Kabupaten Serang

Dalam dunia pendidikan, guru merupakan salah satu faktor terpenting dalam menentukan kualitas hasil belajar siswa. Sebagai tenaga profesional guru dituntut untuk memiliki kinerja yang baik dalam mengerjakan dan menjalankan tugas pembelajaran di sekolah. Kinerja guru dipengaruhi oleh motivasi, kualifikasi, pengalaman, gaji yang di peroleh, lingkungan dan pelatihan yang didapatkan.

Pengembangan sumber daya manusia pendidik menjadi faktor yang akan sangat menentukan dalam mendorong kinerja guru agar semakin lebih baik lagi atau meningkat. Peningkatan tersebut tidak hanya berinplikasi kuantitas namun juga kualitas mengenai bagaimana kinerja mereka di laksanakan, dan dalam konteks perubahan kinerja inovatif menjadi suatu tuntutan yang semakin mendesak untuk dapat dilaksanakan oleh guru dalam melaksanakan peran dan tugasnya sebagi pendidik sehingga dapat melahirkan lulusan yang kreatif dan inovatif yang memiliki daya saing di era global. Dengan dimikian upaya untuk terus mengembangkan kinerja guru menjadi suatu yang amat penting dalam upaya peningkatan kualitas pendidikan, dan hal ini memerlukan menejemen kinerja yang tepat sesusai dengan konteks organisasi sekolah.

Kinerja guru dalam menjalankan tugas akan berpengaruh terhadap mutu pembelajaran dan berdampak pada peningkatan kinerja sekolah. Pengembangan kinerja harus terus dilakukan sehingga mutu sekolah akan terus mengalami peningkatan. Kinerja guru pada akhirnya akan terbentuk propesionalisme guru dan pengembangan kepropesian berkelanjutan. ${ }^{6}$

Guru yang efektif adalah guru yang menguasai mata pelajaran yang diampunya dan mempunyai kemampuan untuk mengajarkan kepada peserta didik. Guru mengetahui kondisi siswa dalam memahami pembelajaran, mampu mengantisipasi dan mendiagnosa siswa yang mengalami kesulitan pada saat proses belajar. Guru merupakan ujung tombak pelaksana pendidikan. Keberhasilan guru dalam melaksanakan tugasnya merupakan cermin dari kinerja guru, dan hal tersebut dari aktualisasi kompetensi guru dalam merealisasikan tugas profesinya.

Gaya kepemimpinan kepala sekolah adalah salah satu faktor yang mempengaruhi kinerja guru yang menjadi tidak maksimal. Ketidak maksimalan kinerja guru antara lain dipicu oleh tidak jelasnya konsep dan penerapan manajemen mutu terpadu di sekolah-sekolah yang diterapkan oleh kepala sekolah. Selama ini, pihak otoritas sekolah kerap berbicara tentang mutu pendidikan, tetapi mereka tidak paham pada konsep dan paparan manajemen mutu terpadu, sesuai dengan salah satu standar nasional pendidikan yaitu standar pengelolaan yang dapat dijadikan tumpuan untuk mencapai mutu yang diharapkan. Akibatnya output

6 Tony Bush dan Marianne Coleman. 2008. Manajemen Strategis Kepemimpinan Pendidikan. Yogyakarta: IRCiSoD, diterjemahkan oleh Fahrurrozi.hlm 95 
Hubungan Gaya Kepemimpinan Transformasional dan Supervisi Kepala Sekolah Serta Iklim Kerja Terhadap Kinerja Guru di SMP Kecamatan Cikande Kabupaten Serang

pendidikan yang dihasilkan oleh sekolah-sekolah tetap tidak bermutu. Kepala sekolah sebagai pimpinan adalah subjek yang harus melakukan transformasi kepemimpinan melalui pemberian bimbingan, tuntunan, atau anjuran kepada yang dipimpinnya agar tujuan sekolah tercapai. Kepala sekolah merupakan personel sekolah yang bertanggung jawab terhadap seluruh kegiatan sekolah. Dalam paradigma baru manajemen pendidikan, kepala sekolah berfungsi sebagai edukator, manajer, administrator, supervisor, leader, inovator dan motivator. ${ }^{7}$ Sehingga dengan demikian peranan kepala sekolah sangat penting dalam mencapai kemajuan pendidikan. Kepala sekolah sebagai pemimpin harus mampu mengambil keputusan yang cepat dan tepat, memberikan petunjuk dan pengawasan, meningkatkan kemauan dan kemampuan tenaga kependidikan, membuka komunikasi dua arah dan mendelegasikan suatu tugas .Kepala sekolah sebagai pemimpin harus mampu memilah dan memilih, serta menerapkan gaya kepemimpinan yang tepat untuk mencapai visi organisasi yang telah ditetapkan secara bersama. Keteladanan, kebersamaan dan keberanian untuk melakukan trobosan baru merupakan ciri dari kepemimpinan transformasional harus nampak dengan jelas di dalam diri kepala sekolah serta diwujudkan secara nyata dengan mengajak semua guru dan staf bekerja secara maksimal demi tercapainya tujuan organisasi. Persoalan tersebut menjadi lebih penting sejalan dengan semakin kompleksnya tuntutan tugas kepala sekolah, yang menghendaki dukungan kinerja yang semakin efektif dan efisien. Dalam fungsinya sebagai seorang pemimpin, kepala sekolah harus dapat memperhatikan kebutuhan dan perasaan orang-orang yang bekerja sehingga kinerja guru selalu terjaga. Penerapan pola kepemimpinan transformasional dapat menunjang terwujudnya perubahan sistem persekolahan.

Kepemimpinan transformasional yaitu pemimpin yang mencurahkan perhatiannya kepada persoalan-persoalan yang dihadapi oleh para pengikutnya dan kebutuhan pengembangan dari masing-masing pengikutnya dengan cara memberikan semangat dan dorongan untuk mencapai tujuannya. ${ }^{8}$

Pemimpin transformasional adalah agen perubahan dan bertindak sebagai katalisator, yaitu memberi peran mengubah sistem kearah yang lebih baik lagi. Katalisator adalah sebutan lain untuk pemimpin transformasional karena ia berperan meningkatkan segala sumber daya manusia yang ada. Berusaha memberiakn reaksi yang menimbulkan semangat dan daya kerja cepat semaksimal mungkin, selalu tampil sebagai pelopor dan pembawa perubahan. ${ }^{9}$

\footnotetext{
${ }^{7}$ Mulyasa,E. 2006. Menjadi Kepala Sekolah Profesional. Bandung: PT Remaja Rosdakarya. hlm.98

${ }^{8}$ Sudaryono. 2014. Leadership Teori dan Praktek Kepemimpianan. Jakarta: Lentera Ilmu Cendekia. hlm.205

${ }^{9}$ Sudaryono. 2014. Leadership Teori dan Praktek Kepemimpianan. Jakarta: Lentera Ilmu Cendekia.hlm 208
} 
ISTIGHNA, Vol. 3, No 2, Juli 2020 P-ISSN 1979-2824

Homepage: http://e-journal.stit-islamic-village.ac.id/index.php/istighna

Naila Attamimi

Hubungan Gaya Kepemimpinan Transformasional dan Supervisi Kepala Sekolah Serta Iklim Kerja Terhadap Kinerja Guru di SMP Kecamatan Cikande Kabupaten Serang

Dari definisi diatas bahwa Kepemimpinan transformasional adalah kepemimpinan yang menekankan pada usaha menstranformasikan nilai-nilai organisasi kepada anggota. Untuk itu pemimpin harus memiliki visi ke depan, memberikan inspirasi secara alami kepada anggota, memberikan perhatian, memberikan memotivasi kepada anggota, merangsang peningkatan kemampuan anggota, sebagai katalisator, dan memberdayakan anggota serta meningkatkan performa anggota untuk mencapai tujuan organisasi.

Kepemimpinan transformasional diuraikan dalam empat ciri utama, yaitu: idealisasi pengaruh, motivasi inspirasional, konsiderasi individual, dan stimulasi intelektual. $^{10}$

Adapun definisi rincian masing-masing ciri utama tersebut adalah sebagaiberikut:

a. Idealisasi Pengaruh (Idealized Influence)

Idealisasi pengaruh adalah perilaku yang menghasilkan standar perilaku yang tinggi, memberikan wawasan dan kesadaran akan visi, menunjukkan keyakinan, menimbulkan rasa hormat, bangga dan percaya, menumbuhkan komitmen dan unjuk kerja melebihi ekspektasi, dan menegakkan perilaku moral yang etis. Pemimpin yang memiliki idealisasi pengaruh akan menunjukkan perilaku antara lain: mengembangkan kepercayaan bawahan kepada atasan, membuat bawahan berusaha meniru perilaku dan mengidentifikasi diri dengan pemimpinnya, menginspirasikan bawahan untuk menerima nilai-nilai, norma-norma, dan prinsip-prinsip bersama, mengembangkan visi bersama, menginspirasikan bawahan untuk mewujudkan standar perilaku secara konsisten, mengembangkan budaya dan ideology organisasi yang sejalan dengan masyarakat pada umumnya. Transformational leaders behave in ways that allow them to serve as role models for their followers. The leaders are admired, respected, and trusted. Followers identify with the leaders and want to emulate them; leaders are endowed by their followers as having extraordinary capabilities, persistence, and determination. In addition, leaders who have a great deal of idealized influence are to take risks and are cinsistent rather than arbitrary. They can be counted on to do the right thing, demonstrating high standards of ethical and moral conduct. ${ }^{11}$ Pemimpin transformasional berprilaku melalui caracara yang membuatnya tampil sebagai model bagi pengikutnya. Pemimpinpemimpin ini dikagumi, dihormati dan dipercaya sehingga pengikut-

${ }^{10}$ Setiawan, Agus Bahar \& Muhit. 2013. Transformational Leadership. Jakarta: PT Raja Grafindo Persada. hlm.153

${ }^{11}$ Bass, BM.and Riggio Ronald E. 2006. Transformational Leadership. Second Edition. New Jersey: Lawrence Elrbaum Associates, Inc 
Hubungan Gaya Kepemimpinan Transformasional dan Supervisi Kepala Sekolah Serta Iklim Kerja Terhadap Kinerja Guru di SMP Kecamatan Cikande Kabupaten Serang

pengikutnya merasa dekat dengan pemimpin serta ingin menjadi seperti pemimpinnya. Para pemimpin ini dipercaya karena memiliki kemampuan yang luar biasa, ketekunan, dan kebulatan tekad. Lebih lanjut lagi, pemimpin yang mempunyai idealized influence yang kuat mampu mengambil resiko dan konsisten daripada bertindak sewenang-wenang. Mereka diperhitungkan dalam melakukan hal-hal yang tepat, memperlihatkan kelakuan moral dan etika berstandar tinggi.

Secara singkat idealized influence berkaitan dengan prilaku kharismatik. Karisma didefinisikan sebagai proses seorang pemimpin dalam mempengaruhi pengikutnya dengan emosi-emosi yang kuat sehingga membuat anggotanya merasa kagum dan segan dengan dirinya. Kharisma merupakan komponen yang dapat menimbulkan pengakuan, penghargaan, dan kepercayaan dari anggotanya. Kharisma muncul dari interaksi, nilai dan perilaku yang ditunjukan pimpinan dengan kepercayaan dan persepsi bawahan. Pimpinan menunjukan perilaku kharismatik melalui cermin etika yang ditampilkan.

\section{b. Motivasi Inspirasional (Inspirational Motivation)}

Motivasi inspirasional adalah sikap yang selalu menciptakan tantangan, untuk mencapai ekspektasi yang tinggi, mampu membangkitkan antusiasme dan motivasi orang lain,serta mendorong seseorang unntuk menciptakan instuisi kebikan yang ada dalam dirinya. Pemimpin mampu membangkitkan semangat anggota tim baik melalui antusiasme maupun optimisme. Pemimpin yang memiliki motivasi inspirasional mampu meningkatkan motivasi dan antusiasme bawahan, membangun kepercayaan diri terhadap kemampuan untuk menyelesaikan tugas dan mencapai sasaran kelompok. Kepemimpinan adalah upaya menggunakan berbagai jenis pengaruh yang bikan paksaan untuk memotivasi anggota organisasi agar mencapai tujuan tertentu. Pada dasarnya memotivasi berarti harus dilakukan sebagai kegiatan mendorong anggota organisasi untuk melakukan pekerjaan atau kegiatan tertentu yang tidak memaksa dan mengarah pada tujuan. Pemimpin yang mempunyai motivasi inspirasional akan menunjukan prilaku membangkitkan gairah bawahannya untuk mengembangkan diri, berkerja maksimal, dan mencapai prestasi terbaik dalam pekerjaanya. ${ }^{12}$

c. Konsiderasi Individual (Individualized Consideration)

Konsiderasi individual adalah sikap yang selalu mendengarkan dengan penuh memberikan perhatian khusus, kepedulian, dukungan, semangat, dan

${ }^{12}$ Sudaryono. 2014. Leadership Teori dan Praktek Kepemimpianan. Jakarta: Lentera Ilmu Cendekia. hlm.5 
ISTIGHNA, Vol. 3, No 2, Juli 2020 P-ISSN 1979-2824

Homepage: http://e-journal.stit-islamic-village.ac.id/index.php/istighna

Naila Attamimi

Hubungan Gaya Kepemimpinan Transformasional dan Supervisi Kepala Sekolah Serta Iklim Kerja Terhadap Kinerja Guru di SMP Kecamatan Cikande Kabupaten Serang

usaha pada diri anggotanya dalam hal prestasi dan pertumbuhan. Pemimpin transformasional memiliki perhatian khusus terhadap kebutuhan setiap individu dalam pencapaian dan pertumbuhan yang mereka harapkan dengan berperilaku sebagai pelatih atau mentor dalam meningkatkan potensi yang mereka miliki. Konsiderasi ini dapat meningkatkan produktivitas dan mempengaruhi kepuasan anggota atau bawahan terhadap atasannya. Konsiderasi ini dapat terlihat dari bagaimana seorang pemimpin memperlakukan bawahannya secara individu dan memberikan penghargaan untuk setiap pekerjaan yang baik.

d. Stimulasi Intelektual (Intelectual Stimulation)

Stimulasi intelektual adalah proses meningkatkan pemahaman dan merangsang timbulnya cara pandang baru dalam melihat suatu permasalahan, cara berpikir, berimajinasi, serta dalam menetapkan nilai-nilai kepercayaan melalui kontribusi intelektual yaitu logika, analisa, dan rasionalitas. Melalui stimulasi intelektual pemimpin dapat merangsang tumbuhnya inovasi dan cara-cara baru dalam menyelesaikan suatu masalah. Melalui proses stimulasi ini akan terjadi peningkatan kemampuan bawahan dalam memahami dan memecahkan masalah, berpikir, dan berimajinasi, juga perubahan dalam nilai-nilai dan kepercayaan mereka. Perubahan ini bukan saja dapat dilihat secara langsung, tetapi juga perubahan jangka panjang yang merupakan lompatan kemampuan konseptual, pemahaman dan ketajaman dalam menilai dan memecahkan suatu masalah.

Keempat dimensi perilaku tersebut merupakan dimensi pokok kepemimpinan transformasional. Perilaku kepemimpinan dilakukan terintegrasi dalam proses pelaksanaan tugas sehari-hari, mulai dari penyampaian visi, misi, dan tujuan organisasi, peningkatan motivasi dan kemampuan anggota, serta pemberdayaan anggota dalam rangka mencapai visi, misi, dan tujuan organisasi yang telah direncanakan sebelumnya.

Selain faktor gaya kepemimpinan transformasional kepala sekolah, faktor kedua yang mempengaruhi kinerja guru adalah supervisi kepala sekolah yaitu supervisi yang dilakukan kepala sekolah. Salah satu tugas kepala sekolah adalah sebagai supervisor, yaitu mensupervisi pekerjaan yang dilakukan oleh tenaga kependidikan. Jika kepala sekolah sebagai supervisor dapat melakukan tugas, fungsi dan tanggung jawabnya dengan baik melaksanakan supervisi pendidikan secara efektif dan profesional maka logikanya pemberian supervisi oleh kepala sekolah akan meningkatkan kinerja guru. Kegiatan supervisi kepala sekolah adalah membantu dan melayani guru melalui penciptaan lingkungan yang kondusif bagipeningkatan kualitas pengetahuan, ketrampilan, sikap, dan kedisiplinan. Supervisi adalah serangkaian usaha pemberian bantuan kepada guru dalam bentuk 
ISTIGHNA, Vol. 3, No 2, Juli 2020 P-ISSN 1979-2824

Homepage: http://e-journal.stit-islamic-village.ac.id/index.php/istighna

Naila Attamimi

Hubungan Gaya Kepemimpinan Transformasional dan Supervisi Kepala Sekolah Serta Iklim Kerja Terhadap Kinerja Guru di SMP Kecamatan Cikande Kabupaten Serang

layanan profesional yang diberikan oleh supervisor guna meningkatkan mutu proses dan hasil belajar-mengajar. ${ }^{13}$ Terdapat beberapa tujuan dari supervisi yaitu: ${ }^{14}$

a. Meningkatkan mutu kinerja guru

1) Membantu guru dalam memahami tujuan pendidikan dan apa peran sekolah dalam mencapai tujuan tersebut.

2) Membantu guru dalam melihat secara lebih jelas dalam memahami keadaan dan kebutuhan siswanya.

3) Membentuk moral kelompok yang kuat dan mempersatukan guru dalam suatu tim yang efektif, berkerjasama secara akrab dan bersahabat serta saling menghargai satu dengan yang lainnya.

4) Meningkatkan kualitas pemeblajarn yang pada akhirnya meningkatkan prestasi belajar siswa.

5) Meningkatkan kualitas pengajaran guru baik itu dari segi strategi, keahlian dan alat pengajaran.

6) Menyediakan sebuah sistem yang berupa penggunaan teknologi yang dapat membantu guru dalam pengajaran.

7) Sebagai salah satu dasar pengambilan keputusan bagi kepala sekolah untuk reposisi guru.

b. Meningkatkan keefektifan kurikulum sehingga berdaya guna dan terlaksana dengan baik.

c. Meningkatkan keefektifan dan keefesiensian sarana dan prasarana yang ada untuk dikelola degan baik.

d. Meningkatkan kualitas pengelolaan sekolah khususnya dalam mendukung terciptanya suasana kerja yang optimal.

e. Meningkatkan situasi umum sekolah sehingga tercipta situasi yang tenang dan tentram serta kondusif.

Fungsi utama supervisi pendidikan ditujukan pada perbaikan dan peningkatan kualitas pengajaran. Fungsi-fungsi tersebut meliputi kegiatan-kegiatan berikut (1) Mengoordinasi semua usaha sekolah, (2) Memperlengkapi kepemimpinan sekolah, (3) Memperluas pengalaman guru-guru, (4) Menstimulasi usaha-usaha sekolah yang kreatif, (5) Memberikan fasilitas dan penilaian terus menerus, (6) Menganalisis situasi belajar mengajar, (7) Memperlengkapi staf dengan pengetahuan dan ketrampilan yang baru, dan (8) Memadukan dan menyelaraskan tujuan-tujuan pendidikan dan membentuk kemampuan-kemampuan. ${ }^{15}$

${ }^{13}$ Muslim, Banun Sri. 2009. Supervisi Pendidikan Meningkatkan Kualitas Profesionalisme Guru. Bandung: Alfabeta. hlm.41

14 Sudadio. 2013. Esensial Multidimensi Manajemen Peningkatan Mutu Terpadu. Serang: DBB Press. hlm. 131-132 Cipta. hlm.21

${ }^{15}$ Sahertian, Piet, Konsep Dasar Dan Teknik Supervisi Pendidikan, 2008, Jakarta: Rineka 
ISTIGHNA, Vol. 3, No 2, Juli 2020 P-ISSN 1979-2824

Homepage: http://e-journal.stit-islamic-village.ac.id/index.php/istighna

Naila Attamimi

Hubungan Gaya Kepemimpinan Transformasional dan Supervisi Kepala Sekolah Serta Iklim Kerja Terhadap Kinerja Guru di SMP Kecamatan Cikande Kabupaten Serang

Dalam fungsinya sebagai bantuan, proses bimbingan dan kendali, maka supervisi menghendaki agar proses pendidikan dapat berjalan lebih baik, efektif dan optimal. Hendaklah perlu disadari bahwa kemajuan sekolah, keberhasilan proses pembelajaran dan pencapaian tujuan pendidikan membutuhkan upaya serius dalam pengelolaannya. Oleh karena itu diperlukan supervisi dan pembinaan secara berkelanjutan, terus-menerus dan sistematis. Harus diupayakan sistem pembinaan yang mudah dipraktikkan, realistis dan objektif sehingga pembinaan ini akan berhasil dan berdaya guna dalam memcahkan masalah (antisipatif), membangun (konstruktif) serta mampu membangkitkan kreativitas. Pendekatan yang digunakan dalam pembinaan hendaknya bersifap kooperatif dan kekeluargaan dengan prinsip : Ing Ngarso Sung Tulodo; Ing Madyo MangunKarso ; Tut Wuri Handayani.

Teknik supervisi terbagi menjadi dua yaitu teknik supervisi yang bersifat individual dan kelompok. Teknik supervisi yang bersifat individual ada tiga jenis yaitu: (1)kunjungan kelas, (2) observasi, (3) percakapan pribadi. Sedangkan teknik yang bersifat kelompok antara lain: rapat guru, diskusi kelompok, loka karya, seminar,dan sebagainya. ${ }^{16}$

Supervisi kunjungan kelas adalah menolong guru dalam hal pemecahan permasalahan yang sedang dihadapi. Dalam kunjungan kelas atau observasi kelas yang diutamakan adalah mempelajari sifat dan kualitas bagaimana cara belajar anak serta bagaimana guru membimbing murid-muridnya. Berdasarkan pendapat tersebut dapat disimpulkan bahwa supervisi kunjungan kelas pada hakekatnya adalah observasi di kelas dengan tujuan untuk menemukan kelemahan dan kelebihan guru dalam mengajar sehingga dapat ditemukan titik permasalahanya, untuk selanjutnya dicarikan jalan keluar dari permasalahan yang dihadapi guru oleh spervisor secara demokratis.

Dapat disimpulkan bahwa fungsi supervisi kunjungan kelas adalah sebagai alat atau kunci untuk mendorong guru agar meningkatkan cara mengajar begitupun dengan para peserta didik agar menemukan cara belajar yang baik dan menyenangkan. Supervisi kunjungan kelas dapat memberikan kesempatan guru untuk mengemukakan pengalamannya sekaligus sebagai usaha untuk memberikan rasa mampu pada guru-guru, karena dapat belajar dan memperoleh pengertian secara moral bagi pertumbuhan karir. Jenis supervisi kunjungan kelas dapatdibedakan menjadi tiga yaitu:

a. Kunjungan Dengan Tanpa Memberitahu

Supervisi yang secara tiba-tiba datang ke kelas pada saat guru mengajar atau semacam sidak tanpa memberitahu terlebih dahulu. Jenis supervisi ini

${ }^{16}$ Sudadio. 2013. Esensial Multidimensi Manajemen Peningkatan Mutu Terpadu. Serang: DBB Press. Hlm 138-139 
Hubungan Gaya Kepemimpinan Transformasional dan Supervisi Kepala Sekolah Serta Iklim Kerja Terhadap Kinerja Guru di SMP Kecamatan Cikande Kabupaten Serang

ada segi positifnya dan segi negatifnya. Segi positifnya yaitu supervisor dapat mengetahui keadaan yang sesungguhnya, sehingga ia dapat menentukan masukan atau solusi yang diperlukan oleh guru tersebut. Kemudian supervisor dapat pula melihatyang sebenarnya tanpa dibuat-buat. Hal seperti ini dapat membiasakan guru agar selalu mempersiapkan diri dengan matang.

Sedangkan kelemahannya adalah guru menjadi gugup, karena dengan tia-tiba supervisor masuk kedalam kelas pada saat proses belajar mengajar berlangsung, lalu akan timbul prasangka bahwa penilaian dari supervisor hasilnya tidak memuaskan. Ada sebagian guru yang tidak senang, bila tibatiba supervisor megadakan kunjungan kedalam kelas tanpa pemberitahuan terlebih dahulu mereka akan berprasangka hanya mencari kesalahan guru.

b. Kunjungan dengan Cara Memberitahu Terlebih Dahulu (Anannounced Visitation)

Supervisi akan memberikan jadwal kunjungan yang telah direncanakan dan diberikan kepada guru yang akan dikunjungi. Jenis supervisi kunjungan kelas dengan diberitahukan lebih dahulu ini juga ada segi positif dan negatifnya.

Segi positifnya adalah pembagian waktu secara merata. Dengan demikian maka akan tercapai efisiensi kerja dan peningkatan dalam proses belajar mengajar, serta guru akan mempersiapkan dengan sebaik mungkin. Sedangkan segi negatifnya adalah guru dengan sengaja mempersiapkan diri, sehingga terjadi kemungkinan akan timbul hal-hal yang dibuat-buat dan berlebihan,sehingga gambaran yang diperoleh supervisor bukan merupakan hasil yang murni.

\section{c. Kunjungan Atas Undangan Guru (Visit UponInvitation)}

Pada jenis supervisi ini guru dengan sengaja memberikan undangan kepada kepala sekolah untuk mengunjungi kelasnya. Jarang sekali terjadi ada seorang guru yang menginginkan kepala sekolahnya melihat atau memperhatikan suasana pada saat proses belajar mengajar berlangsung. Jenis supervisi ini adalah yang terbaik, karena guru secara sadar berupaya dan termotivasi dalam mempersiapkan diri dalam supervisi kelas. Dengan demikian makan akan menciptakan sifat keterbukaan dari guru dan gurupun akan merasa bahwa mereka memiliki hak otonomi dalam jabatannya, aktualisasi kemampuannyapun akan terwujud, sehingga guru selalu belajar untuk selalu mengembangkan diri. Sikap dan dorongan untuk mengembangkan diri ini merupakan alat untuk mencapai proporsional, karena sudah dipersiapkan jauh sebelumnya. 
Hubungan Gaya Kepemimpinan Transformasional dan Supervisi Kepala Sekolah Serta Iklim Kerja Terhadap Kinerja Guru di SMP Kecamatan Cikande Kabupaten Serang

Dari uraian diatas tentang pengertian, tujuan, fungsi, dan jenis-jenis supervisi kunjungan kelas yang masing-masing mempunyai kelebihan dan kelemahan, maka supervisi kunjungan kelas sangat dibutuhkan baik dengan pemberitahuan terlebih dahulu maupun secara tiba-tiba dan tanpa pemberitahuan terlibih dahulu.

Tujuan supervisi kunjungan kelas terlebih dahulu harus dirumuskan secara jelas terutama yang menyangkut situasi proses belajar mengajar. Kegiatan guru mengajar di kelas menjadi primadona, karena pada saat kegiatan proses belajar mengajar terjadi kegiatan interaksi aktif antara guru dengan murid begitupun sebaliknya antara murid dengan guru. Dengan demikian guru dituntut tidak hanya menguasai materi saja tetapi dituntut pandai mengajar sebagai ciri khas keprofesionalannya. Karena itu akan lebih baik bila kepala sekolah (supervisor) melakukan supervisi kunjungan kelas yang sebelumnya telah diprogramkan secara baik, yaitu minimal tiga kali setahun (tiap cawu sekali) dari berbagai jenis supervisi kunjungan kelas.

Disamping itu guru jauh-jauh sebelumnya sudah tahu akan ada supervisi kunjungan kelas, baik itu pemberitahuan secara tertulis (surat resmi) maupun secara lisan (rapat guru) dari kepala sekolah, sehingga guru sadar betul bahwa pelaksanaan supervisi kunjungan kelas oleh kepala sekolah bertujuan tidak hanya mencari kesalahan guru semata, akan tetapi memberi layanan dan bantuan kepada guru agar proses belajar mengajar berjalan dengan baik dan efisien. Mekanisme pelaksanaan supervisi memiliki empat tahap:

a. Tahap penyusunan program supervisi

b. Tahap persiapan

1) Format supervisi

2) Materi supervisi

3) Buku catatan

4) Data supervisi sebelumnya

c. Tahap pelaksanaan

d. Tahap tindak lanjut

Dengan demikian kegiatan supervisi kepala sekolah adalah membantu dan melayani guru melalui penciptaan lingkungan yang kondusif bagi peningkatan kualitas ketrampilan, pengetahuan, , sikap, dan kedisiplinan.

Faktor ketiga yang mempengaruhi kinerja guru dalam penelitian ini adalah iklim kerja. Iklim kerja merupakan salah satu faktor yang cukup berpengaruh terhadap kinerja seseorang kerena akan menentukan pencapaian tujuan yang diharapkan. Iklim kerja adalah keadaan sekitar sekolah, suasana yang sunyi dan nyaman serta kondusif untuk pembelajaran yang dapat meningkatkan prestasi akademik. Iklim kerja sekolah adalah suasana yang terdapat di dalam suatu sekolah. 
ISTIGHNA, Vol. 3, No 2, Juli 2020 P-ISSN 1979-2824

Homepage: http://e-journal.stit-islamic-village.ac.id/index.php/istighna

Naila Attamimi

Hubungan Gaya Kepemimpinan Transformasional dan Supervisi Kepala Sekolah Serta Iklim Kerja Terhadap Kinerja Guru di SMP Kecamatan Cikande Kabupaten Serang

Iklim kerja menggambarkan keadaan warga sekolah dalam keadaan riang dan mesra ataupun kepedulian antara satu dan lainnya. ${ }^{17}$ Hubungan kerja yang mesra tercipta melalui hubungan baik yang terjalin antara kepala sekolah dengan guru, guru dengan peserta didik. Iklim kerja yang harmonis akan menciptakan gairah dan inspirasi dalam bekerja.

Salah satu aspek yang mendukung keberhasilan dalam proses belajar mengajar adalah iklim kerja. Iklim kerja yang kondusif adalah iklim kerja yang sesuai dan mendukung kelancaran serta kelangsungan proses pembelajaran yang dilakukan guru. Untuk itu perlu dipahami beberapa hal yang mempunyai peran penting dalam penciptaan iklim kerja yang kondusif, yaitu lingkungan fisik, dan lingkungan sosial. kedua aspek tersebut dalam proses pembelajaran haruslah saling mendukung.

Lingkungan fisik berhubungan dengan upaya penyegaran, meliputi sarana prasarana pembelajaran yang cukup dan memadai. Sedangkan lingkungan sosial berhubungan dengan pola interaksi antar personal yang ada di lingkungan sekolah. Lingkungan sosial yang baik memungkinkan para warga sekolah berinteraksi secara baik dan efektif, peserta didik dengan peserta didik, guru dengan peserta didik. guru dengan gurunya, atau guru dengan tenaga kependidikan.

Iklim kerja yang kondusif akan memungkinakan setiap guru lebih termotivasi untuk menunjukkan kinerjannya secara unggul, yang disertai usaha untuk meningkatkan kompetensinya. Oleh karena itu, dalam upaya menciptakan iklim kerja yang kondusif, kepala sekolah hendaknya memperhatikan prinsip-prinsip sebagai berikut: (1) para guru akan bekerja lebih giat apabila kegiatan yang dilakuannya menarik dan menyenangkan, (2) tujuan kegiatan perlu disusun dengan jelas dan diinformasikan kepada para guru sehingga mereka mengetahui tujuan dia bekerja, para guru juga dapat dilibatkan dalam penyusunan tujuan tersebut, (3) para guru harus selalu diberitahu teantang dari setiap pekerjaannya,(4) pemebrian hadiah lebih baik dari hukuman, namun sewaktu-waktu hukuman juga diperlukan, (5) usahakan untuk memenuhi kebutuhan sosio-psiko-fisik guru, sehingga memperoleh kepuasan. ${ }^{18}$

Iklim kerja terdiri dari iklim secara fisik dan iklim secara psikologis.Secara fisik misalnya keamanan, kebersihan, kenyamanan, kondisi sarana dan prasarana organisasi (sekolah). Iklim psikologis meliputi lima dimensi, yaitu:Responsibility (tanggung jawab), identity (identitas), warmth (kehangatan), support (dukungan), dan conflict (konflik).

\footnotetext{
${ }^{17}$ Supardi. 2013. Kinerja Guru. Jakarta: PT Raja Grafindo Persada. hlm.121

${ }^{18}$ Mukhtar dan Iskandar. 2013. Orientasi Baru Supervisi Pendidikan. Jakarta: Referensi. hlm.89
} 
ISTIGHNA, Vol. 3, No 2, Juli 2020 P-ISSN 1979-2824

Homepage: http://e-journal.stit-islamic-village.ac.id/index.php/istighna

Naila Attamimi

Hubungan Gaya Kepemimpinan Transformasional dan Supervisi Kepala Sekolah Serta Iklim Kerja Terhadap Kinerja Guru di SMP Kecamatan Cikande Kabupaten Serang

\section{B. METODE PENELITIAN}

Penelitian ini dilaksanakan di Sekolah Menegah Pertama (SMP) di Kecamatan Cikande Kabupaten Serang Provinsi Banten. Desain penelitian yang digunakan untuk menganalisis penelitian mengenai "Hubungan Gaya Kepemimpinan Transformasional, dan Supervisi Kepala, Sekolah, serta Iklim Kerja Terhadap Kinerja Guru Sekolah Menengah Pertama di Kecamatan Cikande Kabupaten Serang Provinsi Banten", adalah penelitian kuantitatif berjenis korelasi karena pada penelitian ini hanya akan melihat hubungan antar variabel yang satu dengan variabel lainnya. Penelitian ini bermaksud menjelaskan hubungan antara variabel gaya kepemimpianan transformasional, supervisi kepala sekolah, dan iklim kerja terhadap kinerja guru. Penelitian ini adalah penelitian analitik (kuantitatif). Metode penelitian yang digunakan dalam penelitian ini adalah yaitu metode survei langsung ke lapangan dengan penyebaran angket/kuesioner.

\section{HASIL PEMBAHASAN DAN PENELITIAN}

Hasil pengujian statistik terhadap ketiga variabel dapat dilihat pada tabel sebagai berikut: 
ISTIGHNA, Vol. 3, No 2, Juli 2020 P-ISSN 1979-2824

Homepage: http://e-journal.stit-islamic-village.ac.id/index.php/istighna

Naila Attamimi

Hubungan Gaya Kepemimpinan Transformasional dan Supervisi Kepala Sekolah Serta Iklim Kerja Terhadap Kinerja Guru di SMP Kecamatan Cikande Kabupaten Serang

\section{Correlations}

\begin{tabular}{|c|c|c|c|c|c|}
\hline & & $\begin{array}{l}\text { Kinerja_Gu } \\
\text { ru }\end{array}$ & $\begin{array}{l}\text { Kepim_Tra } \\
\text { ns }\end{array}$ & $\begin{array}{l}\text { Super_Keps } \\
\text { ek }\end{array}$ & $\begin{array}{l}\text { Iklim_Ke } \\
\text { rja }\end{array}$ \\
\hline $\begin{array}{l}\text { Pearson } \\
\text { Correlation }\end{array}$ & $\begin{array}{l}\text { inerja_Guru } \\
\text { Kepim_Tran } \\
\mathrm{s} \\
\text { Super_Keps } \\
\text { ek } \\
\text { Iklim_Kerja }\end{array}$ & $\begin{array}{l}1.000 \\
.632 \\
.657 \\
.479\end{array}$ & $\begin{array}{l}.632 \\
1.000 \\
.657 \\
.411\end{array}$ & $\begin{array}{l}.657 \\
.657 \\
1.000 \\
.413\end{array}$ & $\begin{array}{l}.479 \\
.411 \\
.413 \\
1.000\end{array}$ \\
\hline Sig. (1-tailed) & $\begin{array}{l}\text { Kinerja_Gur } \\
\text { u } \\
\text { Kepim_Tran } \\
\text { s } \\
\text { Super_Keps } \\
\text { ek } \\
\text { Iklim_Kerja }\end{array}$ & $\begin{array}{l}.000 \\
.000 \\
.000\end{array}$ & $\begin{array}{l}.000 \\
.000 \\
.000\end{array}$ & $\begin{array}{l}.000 \\
.000 \\
.000\end{array}$ & $\begin{array}{l}.000 \\
.000 \\
.000\end{array}$ \\
\hline $\mathrm{N}$ & $\begin{array}{l}\text { Kinerja_Gur } \\
\text { u } \\
\text { Kepim_Tran } \\
\text { s } \\
\text { Super_Keps } \\
\text { ek } \\
\text { Iklim_Kerja }\end{array}$ & $\begin{array}{l}75 \\
75 \\
75\end{array}$ & $\begin{array}{l}75 \\
75 \\
75 \\
75\end{array}$ & $\begin{array}{l}75 \\
75 \\
75\end{array}$ & $\begin{array}{l}75 \\
75 \\
75 \\
75\end{array}$ \\
\hline
\end{tabular}

Dari hasil perhitungan melalui angket menunjukan bahwa gaya kepemimpinan transformasional kepala sekolah mempunyai hubungan yang signifikan terhadap kinerja guru. Keterhubungan variable tersebut ditunjukan pula oleh koefisien korelasi sebesar 0,632. Pada variabel supervisi kepala sekolah mempunyai hubungan yang signifikan terhadap kinerja guru sebesar 0,657. Pada variabel iklim kerja mempunyai hubungan yang signifikan terhadap kinerja guru sebesar 0,479 . 
ISTIGHNA, Vol. 3, No 2, Juli 2020 P-ISSN 1979-2824

Homepage: http://e-journal.stit-islamic-village.ac.id/index.php/istighna

Naila Attamimi

Hubungan Gaya Kepemimpinan Transformasional dan Supervisi Kepala Sekolah Serta Iklim Kerja Terhadap Kinerja Guru di SMP Kecamatan Cikande Kabupaten Serang

Hasil pengujian variabel secara simultan dapat dilihat pada tabel uji korelasi berganda dibawah ini:

\section{Model Summary}

\begin{tabular}{|l|l|l|l|l|}
\hline Model & $\mathrm{R}$ & R Square & $\begin{array}{l}\text { Adjusted } \\
\text { Square }\end{array}$ & $\begin{array}{l}\text { Std. Error of } \\
\text { the Estimate }\end{array}$ \\
\hline 1 & $.731^{\mathrm{a}}$ & .534 & .514 & 4.32105 \\
\hline
\end{tabular}

a. Predictors: (Constant), Iklim Kerja, Kepemimpinan

Transformasional, Supervisi Kepala Sekolah

Berdasarkan tabel Model Summary diketahui bahwa besarnya hubungan antara Gaya kepemimpinan transformasional (X1), dan Supervisi kepala sekolah (X2), serta Iklim kerja (X3) (secara simultan) dengan Kinerja Guru dihitung dengan koefisien korelasi adalah 0,731, hal ini menunjukkan hubungan atau korelasi yang tinggi. Sedangkan kontribusi atau sumbangan secara simultan ( $R$ square) variabel Gaya kepemimpinan transformasional (X1), dan Supervisi kepala sekolah (X2), serta Iklim kerja (X3) (secara simultan) dengan Kinerja Guru adalah 0,534 atau $53,4 \%$.

Selanjutnya hasil perhitungan korelasi ganda menunjukkan bahwa nilai sig $\mathrm{F}$ change sebesar 0,534 lebih besar dari 0,05, maka $\mathrm{H}_{0}$ di tolak dan $\mathrm{H}_{\mathrm{a}}$ diterima. Hal tersebut berarti bahwa ada hubungan yang signifikan antara variabel Gaya kepemimpinan transformasional (X1), dan Supervisi kepala sekolah (X2), serta Iklim kerja (X3) (secara simultan) dengan Kinerja Guru (Y).

\section{KESIMPULAN}

Terdapat hubungan positif antara Gaya Kepemimpinan Transformasional Kepala Sekolah terhadap Kinerja Guru di SMP Kecamatan Cikande Kabupaten Serang.Dapat disimpulkan dimana korelasi variabel gaya kepemimpinan transformasional kepala sekolah (X1) dengan kinerja guru (Y) adalah 0, 632 angka tersebut berada pada Interval Koefisien 0,60-0,799. Hasil uji signifikansi menunjukkan hasil 0,000 dimana hasil tersebut lebih kecil dari 0,05. Hal ini menunjukkan bahwa terdapat hubungan yang signifikan anatara variabel gaya kepemimpinan transformasional kepala sekolah (X1) dengan kinerja guru (Y). Terdapat hubungan positif antara Supervisi Kepala Sekolah(X2) terhadap Kinerja Guru (Y) di SMP Kecamatan Cikande Kabupaten Serang.

Dapat disimpulkan hasil penelitian didapat korelasi variabel supervisi kepala sekolah (X2) terhadap kinerja guru (Y) adalah 0,657, angka tersebut berada pada 
ISTIGHNA, Vol. 3, No 2, Juli 2020 P-ISSN 1979-2824

Homepage: http://e-journal.stit-islamic-village.ac.id/index.php/istighna

Naila Attamimi

Hubungan Gaya Kepemimpinan Transformasional dan Supervisi Kepala Sekolah Serta Iklim Kerja Terhadap Kinerja Guru di SMP Kecamatan Cikande Kabupaten Serang

interval koefisien 0,60-0,799. Hasil uji signifikansi menunjukkan hasil 0,000 dimana hasil tersebut lebih kecil dari 0,05. Hal ini menunjukkan bahwa terdapat hubungan yang signifikan antara variabel antara Supervisi Kepala Sekolah(X2) terhadap Kinerja Guru (Y). Terdapat hubungan positif antara Iklim Kerja (X3) terhadap Kinerja Guru (Y) di SMP Kecamatan Cikande Kabupaten Serang. Dapat disimpulkan hasil penelitian didapat korelasi variabel Iklim Kerja (X3)terhadap kinerja guru (Y) adalah 0,479, angka tersebut berada pada interval koefisien 0,400,599. Hasil uji signifikansi menunjukkan hasil 0,000 dimana hasil tersebut lebih kecil dari 0,05. Hal ini menunjukkan bahwa terdapat hubungan yang signifikan antara variabel antara variabel Iklim Kerja (X3)(X2) terhadap Kinerja Guru (Y). Terdapat hubungan yang positif antara Gaya Kepemimpinan Transformasional (X1), dan Supervisi Kepala Sekolah (X2), serta Iklim kerja (X3) terhadap Kinerja Guru (Y)di SMP Kecamatan Cikande Kabupaten Serang.Dapat disimpulkan uji korelasi ganda dalam Model Summary diketahui bahwa besarnya hubungan antara Gaya Kepemimpinan Transformasional (X1), dan Supervisi Kepala Sekolah (X2), serta Iklim kerja (X3) secara simultan terhadap Kinerja Guru (Y) yang dihitung dengan koefisien korelasi adalah 0,731 , hal ini menunjukkan pengaruh yang yang tinggi. Sedangkan kontribusi atau sumbangan secara simultan ( $R$ square) variabel $\backslash$ Gaya Kepemimpinan Transformasional (X1), dan Supervisi Kepala Sekolah (X2), serta Iklim kerja (X3) dengan Kinerja Guru (Y) adalah 0,534 atau 53,4\%.

\section{DAFTAR PUSTAKA}

Aqib, zainal. 2010. Menjadi Guru Profsional Berstandar Nasional. Bandung: Yrama Widya

Bass BM. and Riggio Ronald E. 2006. Transformational Leadership. Second Edition. New Jersey: Lawrence Elrbaum Associates, Inc

Hosnan. 2013. Kamus Profesional Guru. Jakarta: Yudhistira H.174

Kusnandar. 2011. Guru Profesional Implementasi Kurikulum Tingkat Satuan Pendidikan (KTSP) dan Sukses dalam Sertifikasi Guru. Jakarta: Raja Garafindo.

Mukhtar dan Iskandar. 2013. Orientasi Baru Supervisi Pendidikan. Jakarta: Gaung Persada

Mulyasa,E. 2006. Menjadi Kepala Sekolah Profesional. Bandung: PT Remaja Rosdakarya.

Muslim, Banun Sri. 2009. Supervisi Pendidikan Meningkatkan Kualitas Profesionalisme Guru. Bandung: Alfabeta. 
ISTIGHNA, Vol. 3, No 2, Juli 2020 P-ISSN 1979-2824

Homepage: http://e-journal.stit-islamic-village.ac.id/index.php/istighna

Naila Attamimi

Hubungan Gaya Kepemimpinan Transformasional dan Supervisi Kepala Sekolah Serta Iklim Kerja Terhadap Kinerja Guru di SMP Kecamatan Cikande Kabupaten Serang

Sahertian, Piet. 2008. Konsep Dasar Dan Teknik Supervisi Pendidikan. Jakarta : Rineka Cipta.

Setiawan, Agus Bahar dan Muhit. 2013. Transformational Leadership. Jakarta: PT Raja Grafindo Persada. hlm.153

Suhar Saputra. 2010. Administrasi Pendidikan. Bandung: Refika Aditama.

Sudadio. 2013. Esensial Multidimensi Manajemen Peningkatan Mutu Terpadu. Serang: DBB Press

Sudaryono. 2014. Leadership Teori dan Praktek Kepemimpianan. Jakarta: Lentera Ilmu Cendekia

Supardi. 2013. Kinerja Guru. Jakarta: PT Raja Grafindo Persada.

Tony Bush dan Marianne Coleman. 2008. Manajemen Strategis Kepemimpinan Pendidikan. Yogyakarta: IRCiSoD, diterjemahkan oleh Fahrurrozi. 